\title{
Video Edukasi Covid-19 Bagi Masyarakat Untuk Meningkatkan Tanggung Jawab Warga Negara yang Baik
}

\author{
Sarkadi*1 ${ }^{2}$,Syifa Syarifa ${ }^{2}$ \\ ${ }^{12}$ Universitas Negeri Jakarta \\ E-mail: sarkadi@unj.ac.id
}

\begin{tabular}{ll}
\hline Article History: & Abstrak: \\
Received: Desember & Untuk menghadapi pandemi Covid-19 di \\
Revised: Desember & Indonesia, pemerintah dan masyarakat sebagai \\
Accepted: Desember & warga negara yang baik seharusnya dapat \\
Available online: & saling bekerja sama, saling mendukung dan \\
Desember & saling berisinergi. Akan tetapi masih banyak \\
& masyarakat yang tidak peduli. Solusi yang \\
& ditawarkan adalah dengan menyampaikan \\
& video edukasi Covid-19 melalui instagram \\
Kata Kunci:Covid-19, & sebagai media sosial yang mudah diakses dan \\
Edukasi, Instagram, & paling banyak digunakan. Pendekatan \\
Video, & penelitian yang digunakan adalah pendekatan \\
& kualitatif dengan menggunakan metode \\
& survey dengan teknik kuesioner. Data dalam \\
& penulisan ini diperoleh dari hasil kuisioner \\
& yang disebar kepada 40 (empat puluh) \\
& responden melalui google from. Kegiatan ini \\
& berhasil diselenggarakan dengan baik. \\
& Keberhasilan kegiatan ini dapat dilihat dari \\
& adanya respon positif dari responden dan \\
& meningkatnya tanggung jawab responden \\
& sebagai warga negara yang baik.
\end{tabular}




\section{Pendahuluan}

Pandemi Coronavirus disease 2019 (Covid-19) telah menjadi ketakutan dunia sejak pertama kali ditemukan pada akhir tahun 2019 di Wuhan, Tiongkok. Virus ini dapat menyebabkan penyakit saluran pernapasan dengan berbagai gejala, umumnya seperti flu, batuk, demam, hingga pneumonia. Sumber asal dan penularannya ke manusia tidak diketahui, namun penularan yang cepat dari manusia ke manusia telah dikonfirmasi secara luas (Shereen et.al. 2020). Kini, Covid-19 telah menyebar ke berbagai negara, termasuk Indonesia. Jumlah kasus penyebaran Covid-19 di Indonesia terus mengalami peningkatan dalam waktu yang singkat. Sebagai negara dengan populasi terbanyak keempat di dunia, Indonesia memiliki risiko infeksi dalam jumlah besar dan penyebaran virus yang tinggi (Hamid, 2020). Oleh karena itu, untuk memutus mata rantai penyebaran Covid-19, pemerintah juga mengintruksikan kepada masyarakat untuk mematuhi protokol kesehatan mulai dari menerapkan pola hidup bersih, social distancing hingga pemberlakuan Pembatasan Sosial Berskala Besar (PSBB). Akan tetapi, masih saja ada masyarakat yang tidak mematuhi aturan tersebut. Misalnya, berkerumun atau mengadakan kegiatan di tempat umum, beraktivitas di luar rumah tanpa menjaga jarak, acuh terhadap keadaan sekitar dan nekat mudik ke kampung halaman. Selain itu, sikap sebagian masyarakat yang terkesan acuh, mementingkan diri sendiri dan tidak peduli juga menjadi polemik akhirakhir ini. Misalnya, rasa takut yang berlebihan terhadap penyebaran Covid-19 membuat masyarakat di wilayah tertentu menolak apabila daerahnya dijadikan tempat penguburan korban Covid-19 meskipun pemulasaran jenazah telah dilakukan sesuai prosedur. Adapun kasus lainnya yaitu masyarakat tega mengusir tenaga medis yang tinggal di wilayahnya. Sebagai contoh, Persatuan Perawat Nasional Indonesia (PPNI) mengungkapkan adanya penolakan terhadap dokter dan perawat pasien Covid-19 oleh tetangga di lingkungan tempat tinggal mereka di Jakarta Timur (Saragih, 2020). Tiga perawat Rumah Sakit Umum Daerah (RSUD) Bung Karno, Surakarta, juga diusir dari tempat indekos mereka di Kecamatan Grogol, Kabupaten Sukoharjo, Jawa Tengah (CNN Indonesa, 2020). 
Keterlibatan warga negara (civic engagement) adalah hal yang sangat penting dalam mendukung upaya pemerintah menangani Covid-19. Pemerintah dan masyarakat sebagai warga negara yang baik dan cerdas harusnya memiliki semangat solidaritas, saling mendukung dan saling bersinergi dalam menghadapi Covid-19. Kepedulian dan keterlibatan warga negara adalah bagian dari tanggung jawab warga negara yang baik. Warga negara yang baik adalah yang memiliki kepedulian terhadap keadaan, memegang teguh prinsip etika dalam berhubungan dengan sesama, mampu untuk mengajukan gagasan atau ide-ide kritis dan menentukan pilihan atas dasar pertimbangan yang baik (Nurmalina \& Syaifullah, 2008). Bahkan, pembentukan warga negara yang baik (good citizenship) menjadi salah satu misi utama dari pendidikan nasional Indonesia (Suyato et.al. 2016). Warga negara yang baik memiliki karakter yang baik. Karakter baik meliputi tiga hal, yakni mengetahui yang baik (knowing the good), merasakan hal baik (feeling the good) dan melakukan hal baik (acting the good) (Lickona, 1991).

Upaya yang dapat dilakukan untuk meningkatkan rasa tanggung jawab masyarakat sebagai warga negara yang baik di tengah pandemi Covid-19 dan pentingnya mematuhi anjuran pemerintah yaitu dengan memberikan pengetahuan mengenai Covid-19 dengan video edukasi yang dapat disampaikan melalui media sosial. Salah satu media sosial yang paling banyak diminati dan digunakan banyak orang adalah Instagram. Penelitian terkait pemanfaatan video edukasi melalui Instagram dalam kegiatan pendidikan telah dilakukan oleh beberapa peneliti. Misalnya Turyati, Muchtarom \& Winarno (2016), hasil penelitiannya menunjukkan bahwa terdapat pengaruh penggunaan media video edukasi terhadap hasil belajar siswa. Selanjutnya Batubara \& Ariani (2016), hasil penelitiannya menunjukkan bahwa keunggulan video sebagai media pembelajaran mudah digunakan dan mampu menjelaskan konten dengan lebih nyata. Kemudian Pujiati dkk (2019), hasil penelitiannya menunjukkan bahwa Instagram telah berhasil memotivasi siswa untuk belajar bahasa Inggris dan meningkatkan kompetensi bahasa Inggris mereka. Lalu Rubiyati et.al.(2018), hasil penelitiannya menunjukkan bahwa terdapat pengaruh positif yang signifikan antara pemanfaatan media sosial instagram terhadap kreativitas belajar. Kondisi pandemi Covid-19 yang 
dihadapi masyarakat dan penelitian-penelitian tersebut kemudian menginspirasi pengabdian kali ini untuk memanfaatkan Video Edukasi Covid19 Melalui Instagram Untuk Meningkatkan Tanggung Jawab Warga Negara yang Baik.

\section{Metode}

Pengabdian ini dilakukan secara online dengan merumuskan materi edukasi Covid-19 yang kemudian dibuat dalam bentuk video pembelajaran yang menarik. Video edukasi yang dibuat terdiri dari lima video dengan tema yang berbeda dan berkaitan dengan tanggung jawab warga negara yang baik. Adapun judul dari masing-masing video tersebut yaitu ; 1) sikap empati terhadap tenaga medis, 2) sikap dan keterimaan masyarakat terhadap pasien terinfeksi Covid-19, 3) sikap dan keterimaan masyarakat yang daerahnya dijadikan tempat penguburan korban Covid-19, 4) sikap masyarakat yang daerahnya dijadikan wilayah karantina Covid-19, dan 5) sikap masyarakat terhadap mereka yang sembuh dari Covid-19. Alat yang digunakan adalah kamera, laptop, handphone, serta pemanfaatan aplikasi instagram. Video edukasi Covid-19 yang dibuat kemudian diunggah melalui instagram agar pesannya tersampaikan kepada masyarakat umum yang merupakan sasaran pengabdian.

Pendekatan yang digunakan adalah pendekatan kualitatif dengan menggunakan metode survey dan teknik kuesioner. Data yang dikumpulkan diperoleh dari kuesioner yang disebar melalui google form kepada 40 (empat puluh) responden yang merupakan pengguna instagram yang telah diarahkan untuk menonton video edukasi Covid-19 sebagai sampel dari populasi untuk mengisi kuesioner berkaitan dengan pemanfataan video pembelajaran melalui instagram untuk meningkatkan tanggung jawab warga negara yang baik. Adapun langkah-langkah yang ditempuh dapat digambarkan sebagai berikut: 


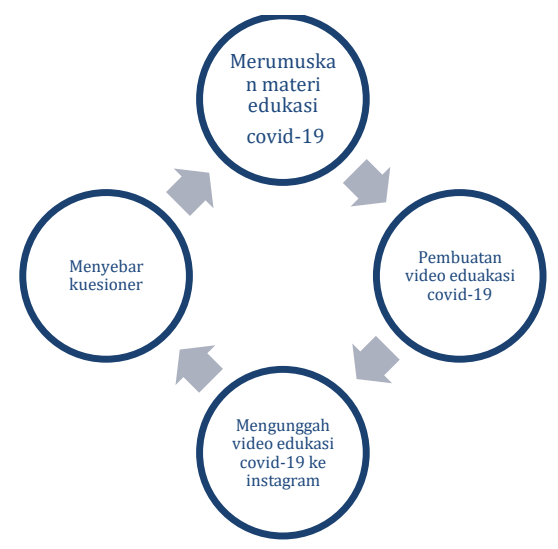

Gambar 1. Diagram langkah-langkah kegiatan

\section{Hasil}

Berdasarkan hasil kuesioner yang telah disebar menunjukkan hasil sebagai berikut :

Tabel. 1 Hasil Kuesioner

\begin{tabular}{clcccc}
\hline No & \multicolumn{1}{c}{ Pernyataan } & SS & S & TS & STS \\
\hline 1 & Video ini efektif untuk mengedukasi masyarakat & $50 \%$ & $47,5 \%$ & $2,5 \%$ & - \\
\hline 2 & $\begin{array}{l}\text { Video ini memudahkan saya untuk mempelajari bagaimana } \\
\text { cara bersikap menghadapi Covid-19 }\end{array}$ & $42,5 \%$ & $55,5 \%$ & $2,5 \%$ & - \\
\hline 3 & Video ini menarik untuk ditonton & $45 \%$ & $55 \%$ & - & - \\
\hline 4 & Video ini menyajikan Informasi yang relevan & $50 \%$ & $42,5 \%$ & $5 \%$ & $2,5 \%$ \\
\hline 5 & Video ini mudah dipahami & $50 \%$ & $50 \%$ & - & - \\
\hline 6 & Video ini penting untuk mengedukasi masyarakat & $57,5 \%$ & $42,5 \%$ & - & - \\
\hline 7 & $\begin{array}{l}\text { Pemanfaatan Instagram dalam menyebarkan video ini } \\
\text { sudah tepat karena mudah diakses }\end{array}$ & $50 \%$ & $42,5 \%$ & $5 \%$ & $2,5 \%$ \\
\hline 8 & Instagram mudah untuk digunakan & $55 \%$ & $42,5 \%$ & $2,5 \%$ & - \\
\hline 9 & $\begin{array}{l}\text { Pembuat video sudah berpartisipasi dalam mendukung } \\
\text { pemerintah }\end{array}$ & $62,5 \%$ & $32,5 \%$ & $5 \%$ & - \\
\hline 10 & $\begin{array}{l}\text { Sebagai wujud peduli, saya membagikan konten ini kepada } \\
\text { teman, keluarga, maupun orang terdekat }\end{array}$ & $35 \%$ & $50 \%$ & $15 \%$ & - \\
\hline & $\begin{array}{l}\text { Sebagai warga negara yang baik, saya akan menerapkan } \\
\text { apa yang saya pelajari dari konten ini dalam kehidupan } \\
\text { bermasyarakat }\end{array}$ & $55 \%$ & $45 \%$ & - & - \\
\hline 12 & $\begin{array}{l}\text { Sebagai warga negara yang baik, saya tertarik untuk } \\
\text { melakukan hal yang sama }\end{array}$ & $35 \%$ & $57,5 \%$ & $7,5 \%$ & - \\
\hline
\end{tabular}




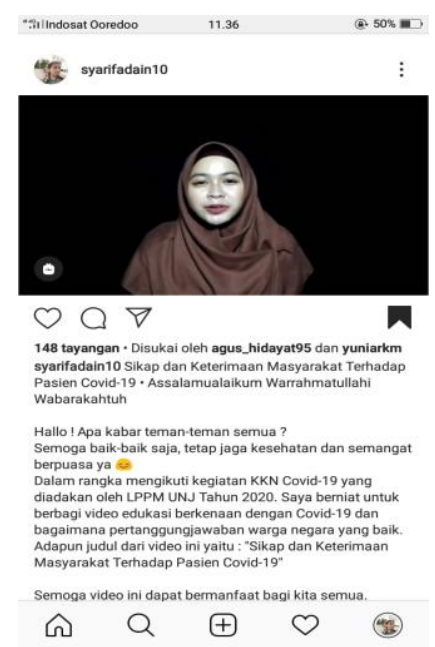

Gambar 2. Dokumentasi Penyampaian Video Edukasi

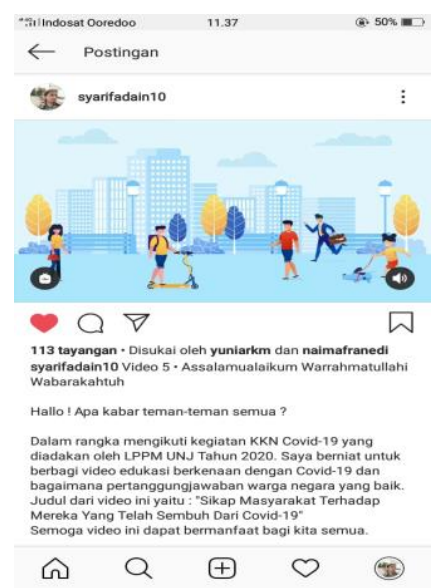

Gambar 3. Dokumentasi Penyampaian Video Edukasi Animasi

\section{Diskusi}

Media pembelajaran video merupakan alat yang dapat digunakan untuk menyampaikan materi pembelajaran melalui tayangan gambar bergerak dan diproyeksikan membentuk karakter yang sama dengan obyek aslinya (Johari et.al 2014) Pemilihan video sebagai media penyebarluasan inovasi selain dapat mengombinasikan visual dengan audio juga dapat dikemas 
dengan berbagai bentuk, misalnya menggabungkan antara komunikasi tatap muka dengan komunikasi kelompok, teks, audio dan musik (Yudianto, 2017). Tingkat retensi (daya serap dan daya ingat) peserta didik terhadap materi pelajaran dapat meningkat secara signifikan apabila proses penerimaan informasi awalnya lebih besar melalui indra pendengaran (audio) dan penglihatan (visual) (Agustiningsih, 2015).

Dalam situasi penyebaran Covid-19 yang mengharuskan setiap orang untuk menjaga jarak dan berdiam diri di rumah, Instagram dapat menjadi alternatif untuk tetap dapat bersosialisasi dan memperoleh konten-konten edukatif. Instagram adalah aplikasi yang dapat digunakan untuk berbagi foto dan video dengan pengikut (followers). Pengguna maupun pengikut dapat melihat, mengomentari, maupun menyukai postingan foto atau video yang dibagikan. Dengan menggunakan Instagram pengguna bebas berbagi cerita dan pengalaman dengan tidak dibatasi jarak dan waktu dengan followers-nya (Sakti \& Yulianto, 2018). Selain itu, Instagram juga dapat dimanfaatkan dalam proses pembelajaran dengan membagikan konten-konten edukatif baik bagi peserta didik maupun masyarakat luas. Dengan adanya Instagram, remaja juga dapat memperoleh ide yang kreatif untuk belajar ketika dirumah maupun di sekolah (Rubiyati et.al. 2018)

Kegiatan pengabdian ini diawali dengan pembuatan video edukasi yang kemudian di unggah ke dalam Instagram agar dapat ditonton dan dipahami oleh khalayak. Setelah disebarkan dan ditonton oleh masyarakat umum, selanjutnya disebarkan instrumen yang berisi 12 (dua belas) pernyataan berkaitan dengan pemanfataan video pembelajaran melalui instagram untuk meningkatkan tanggung jawab warga negara yang baik. Hasil kuesioner yang telah disebar menunjukkan adanya respon positif dari masyarakat, khususnya berkaitan dengan sikap sebagai warga negara yang baik dalam menghadapi pandemi Covid-19.

Berdasarkan hasil kuesioner, dapat dikatakan dari 40 (empat puluh) responden, sebanyak 50\% menyatakan sangat setuju dan 47,5\% setuju bahwa video ini efektif untuk mengedukasi masyarakat. Video ini memuat konten edukatif berkenaan dengan Covid-19 dan tanggung jawab warga negara yang baik. Dalam hal ini, responden memperoleh informasi-informasi bermanfaat 
tentang bagaimana cara bersikap sebagai warga negara yang baik dalam menghadapi Covid-19. Hal ini didukung dengan sebanyak 42,5\% responden menyatakan sangat setuju, dan 55\% setuju jika video yang disampaikan memudahkan mereka untuk mempelajari bagaimana cara bersikap menghadapi Covid-19. Untuk menarik perhatian penonton, video ini dikemas dengan menarik. Sehingga, sebanyak $45 \%$ responden menyatakan sangat setuju dan sisanya yaitu 55\% setuju apabila video ini menarik untuk ditonton.

Berkenaan dengan materi yang disampaikan dalam video, sebanyak $50 \%$ responden sangat setuju, dan $42,5 \%$ setuju. Materi yang disampaikan pun diupayakan agar mudah dipahami. Sehingga sebanyak 50\% responden menyatakan sangat setuju dan $50 \%$ setuju, artinya semua responden setuju bahwa video ini mudah dipahami. Selain itu, sebanyak 57,5\% responden sangat setuju dan $42,5 \%$ setuju bahwa video ini penting untuk mengedukasi masyarakat. Dari sisi pemanfaatan instagram dalam menyampaikan video edukasi, sebanyak $50 \%$ responden sangat setuju dan $42,5 \%$ setuju jika pemanfaatan instagram dalam menyebarkan video edukasi tersebut dianggap sudah tepat karena mudah diakses. Sebanyak $55 \%$ responden sangat setuju dan $42,5 \%$ setuju bahwa instagram mudah untuk digunakan.

Dilihat dari sisi pembuat video, sebanyak $62,5 \%$ responden sangat setuju dan 32,5\% lainnya setuju bahwa pembuat video sudah berpartisipasi dalam mendukung pemerintah menghadapi Covid-19. Sementara itu, dari sisi responden sebagai audiens/followers, sebanyak 50\% menyatakan sangat setuju dan 35\% lainnya setuju untuk membagikan konten tersebut kepada teman, keluarga, maupun orang terdekat sebagai wujud peduli. Sikap peduli merupakan salah satu sikap yang dimiliki oleh warga negara yang baik sebagai tanggung jawab terhadap sesama. Kemudian sebanyak 55\% responden sangat setuju dan $45 \%$ lainnya setuju bahwa sebagai warga negara yang baik, mereka akan menerapkan apa yang dipelajari dari video dalam kehidupan bermasyarakat. Selanjutnya, sebanyak $57,5 \%$ responden setuju dan 35\% sangat setuju, bahwa sebagai warga negara yang baik, mereka tertarik untuk melakukan yang hal sama. Dalam hal ini, yaitu juga turut serta berpartisipasi dengan membuat video edukasi seperti yang dibuat oleh dalam pengabdian 
ini.

\section{Kesimpulan}

Berdasarkan hasil kuesioner, kegiatan pengabdian ini dapat dikatakan berhasil. Keberhasilan ini dapat dilihat dari hasil kuesioner yang menunjukkan bahwa konten video edukasi ini dinilai efektif, mudah dipahami dan penting untuk mengedukasi masyarakat dalam mendukung pemerintah menghadapi Covid-19. Pemanfaatan instagram dalam menyebarluaskan video ini juga dinilai tepat oleh responden karena digunakan banyak orang dan mudah diakses. Pembuat konten juga dianggap sudah berpartisipasi untuk mendukung pemerintah mengedukasi masyarakat dalam menghadapi Covid19. Kegiatan ini berhasil untuk meningkatkan kesadaran dan kepedulian untuk menerapkan pesan-pesan edukasi yang diperoleh dalam kehidupan bermasyarakat yang pada gilirannya dapat meningkatkan rasa tanggung jawab sebagai warga negara yang baik di masa pandemi Covid-19.

\section{Pengakuan/Acknowledgements}

Ucapan terima kasih dihaturkan kepada Universitas Negeri Jakarta yang telah mendanai kegiatan pengabdian masyarakat ini melalui Keputusan Rektor Nomor 464/UN39/KU.00.01/2020 sehingga kegiatan dapat berjalan dengan baik dan memberikan manfaat nyata kepada masyarakat. Terima kasih juga kepada segenap tim pengabdian yang telah terlibat baik secara langsung maupun tidak langsung dalam menyukseskan program pengabdian ini.

\section{Daftar Referensi}

Agustiningsih. (2015). Video Sebagai Alternatif Medi Pembelajaran Dalam Rangka Mendukung Keberhasilan Penerapan Kurikulum di Sekolah Dasar. Pancaran, 55-68.

Batubara, H. H., \& Ariani, D. N. (2016). Pemanfaatan Video sebagai Media Pembelajaran Matematika SD/MI. Muallimuna Jurnal Madrasah Ibtidaiyah, 47-66.

CNN Indonesia. (2020, April 27). 3 Perawat Diusir dari Kos, RS di Solo Jemput Pakai Ambulans. Diambil kembali dari CNN Indonesia: https://www.cnnindonesia.com/nasional/20200427164601-20- 
497756/3-perawat-diusir-dari-kos-rs-di-solo-jemput-pakai-ambulans Gusmadi, S. (2018). Keterlibatan Warga Negara (Civic Engagement) dalam

Penguatan Karakter Peduli Lingkungan. Jurnal Pendidikan Ilmu-Ilmu Sosial, 31-37.

Hariandy Hamid, A. R. (2020). Social responsibility of medical journal: a concern for COVID-19 pandemic. Medical Journal of Indonesia, 1-3.

Johari, A., Hasan, S., \& Rakhman, M. (2014). Penerapan Media Video dan Animasi Pada Materi Memvakum dan Mengisi Refrigeran Terhadap Hasil Belajar Siswa. Journal of Mechanical Engineering Education, 815.

Lickona, T. (1991). Educating for Character How Our School Can Teach Respect and Responsibility. New York: Bantam Books.

Nurmalina, K., \& Syaifullah. (2008). Memahami Pendidikan Kewarganegaraan. Bandung: Lab PKn.

Pujiati, H., Zahra, \& Tamela, E. (2019). The Use of Instagram to Increase Students' Motivation and Students' Competence in Learning English. 1st International Conference on Education, Social Sciences and Humanities (ICESSHum 2019) (hal. 651-656). Atlantis Press.

Rubiyati, Asrori, M., \& Wicaksono, L. (2018). Pengaruh Pemanfaatan Media Sosial Instagram Terhadap Kreativitas Belajar Pada Remaja Kelas VII. Jurnal Pendidikan dan Pembelajaran Khatulistiwa, 1-8.

Sakti, B. C., \& Yulianto, M. (2018). Penggunaan Media Sosial Instagram dalam Pembentukan Identitas Diri Remaja . Interaksi Online, 1-12.

Saragih, S. (2020, Mei 2). Miris! Diusir Warga, Petugas Medis Covid-19 Terpaksa Tidur di RS. Diambil kembali dari Media Indonesia: https://mediaindonesia.com/read/detail/298870-miris-diusir-wargapetugas-medis-covid-19-terpaksa-tidur-di-rs

Shereen , A. M., Khan, S., Kazmi, A., Bashir, N., \& Siddique, R. (2020). COVID-19 infection: origin, transmission, and characteristics of human coronaviruses. Journal of Advanced Research., 1-26.

Suyato, Murdiono, M., Mulyono, B., \& Arpannudin, I. (2016). Upaya Pembentukan Warga Negara Yang Baik Dan Tantangan Yang DIhadapi Oleh Guru PKn Peserta SM3T 2015. Jurnal Civics, 137-150.

Turyati, Muchtarom, M., \& Winarno. (2016). Pengaruh Pengunaan Media Video Edukasi Terhadap Hasil Belajar PKn Siswa Kelas VII SMP Negeri Gondangrejo. PKn Progresif, 257-267.

Yudianto, A. (2017). Penerapan Video Sebagai Media Pembelajaran. Seminar Nasional Pendidikan, 234-237. 